\title{
“WRITING IS AS MUCH AS PICKING OUT AND PASSING OVER" TRACES OF A DIARY IN RYSZARD KAPUŚCIŃSKI'S LAPIDARIUM ${ }^{1}$
}

\author{
by Wioletta Bogucka
}

Although the work of Ryszard Kapuściński has been the subject of a number of academic papers, the six volumes of Lapidarium remain relatively little-known. Researchers investigating the oeuvre of the Polish reporter and writer often pointed out the "diaristic nature of the cycle" (Horodecka, 2010, p. 312), placed it "somewhere between a journal of the books he read, an essay, a collection of aphorisms, and an intimate diary" (Grochowski, 2000, p. 122), or called it a "rough silva rerum" (Nowacka \& Ziątek, 2008, p. 276). Always situated somewhere in-between, Lapidarium is a hybrid of literary genres. Nonetheless, so far no analysis has tackled the work in a manner thorough enough to distinguish theoretical bases of the genre's characteristics.

In my article, I try to distinguish the features of Lapidarium which constitute the work's diary-like character; I also trace out the process of the subject revealing himself in the six volumes of writings. Special attention is given to the textual dimension of the work, that is, what topics are mentioned by the subject when speaking in the first person, and what when using the plural or addressing himself indirectly. Moreover, I examine the following issues: does Ryszard Kapuściński-a character emerging from Lapidarium know how to cope with his own self, his ' $\mathrm{I}$ ', with the Ryszard Kapuściński existing in real life, beyond art and literature? In addition,

1 This article is based on an unpublished doctoral dissertation, Masks and Faces of Ryszard Kapuścinski, written under the direction of Sławomir Buryła, professor of the University of Warmia and Mazury (Olsztyn 2013). 
I consider what practical dimension was attributed to the diary notes and to what extent they could be described as having a causative, disciplining function (the concept of a soliloquy seems relevant here). I also discuss the differences between the entries which have and have not been published as books.

\section{$\cos$}

Lapidarium is a collection of reflections spanning the years 1972-2006. The first volume came out in 1990, with the subsequent ones following in 1995, 1997, 2000, 2002, 2007. The cycle has its origins in the imposition of the martial law in Poland, or, more precisely, in its consequences: "the editorial staff of the Kultura (Culture) weekly, for which I had worked, was disbanded, and just like all my friends back then I found myself unemployed. It deeply upset the order of my life. For many years, I had been following the same rhythm: go to gather materials for reportage, come back, write, then go again, come back and write, leave, come back, and so on. Until that moment, when I stopped. I had no obligations, no deadlines to meet, so I went for other, more personal means of expression," explains Kapuściński (2008b, p. 136).

First-person statements, bringing out the conscious voice of Ryszard Kapuściński, usually concern the act of writing. The first instance appears on page 61 of the first volume of Lapidarium. Using the metaphor of a ship, the author constructs a vision reflecting the individual's mood: "Whenever I walk around Manhattan, it always seems as if I were aboard a large ship. I have a feeling that everything around me is constantly rocking. The skyscrapers are like gigantic masts, with herds of clouds passing overhead. One can feel the sea. It's somewhere here, beneath me" (Kapuściński, 2007a, p. 61).

A sense of uncertainty, conveyed here via the symbolism of the water, a feeling of the lack of solid ground under the feet, a foundation that provides support, becomes twice as telling if we relate it to a theme of obsession, which is clearly evident throughout Lapidarium. The obsession concerns a broadly understood loss and waste of time that could have been dedicated to working-or, in other words, to writing:

11 September 2001

Each day is important, each hour. I can feel the time hurrying me up, I feel its pressure. Anxiety in me. Continuous remorse due to lost moments. Aversion to anything that is not writing, not designing a new text, a book. (ibid., p. 163) 
8 April 2003

Horrendous! The order of my day resembles an agenda of a major corporation or of the president of a large company rather than the way of spending time by a writer, who needs above all peace and quiet, some hours off from distracting side tasks that make you lose your focus. (Kapuściński, 2008a, p. 241)

19 April 2003

As years go by, I glance at my watch ever more often, involuntarily. It always produces astonishment mixed with horror: "It's already nine!" (in the morning). "It's already eight!" (in the evening). I've never happened to say with contentment: “Oh, it's only nine!" or: "Oh, it's only eight!"

My time rushes, doesn't slow down, won't stop even for a moment. (ibid., p. 244)

Psychological criteria of time measurement: I used to count it in years, then in months, today, increasingly more often, in days. I feel a growing dislike of those who steal my time. Even though they often have the best of intentions, I find it hard to accept that someone takes my time from me, time that's essentially irrecoverable. (ibid., p. 245)

The fear of losing time and not using it for creative work has had a significant impact on the author's relations with his surroundings, and prompts the question: 'Why has writing been so important for Kapuściński?' In Modernity and Self-Identity, Anthony Giddens (1991, p. 44) discusses the possibility of substituting "anxiety" with a "symptom": "Anxiety is substitutive: the symptom replaces the anxiety, which is 'swallowed up' by the rigid pattern of behaviour that is adopted. The pattern is nonetheless a tensionful one, because an uprush of anxiety occurs when the person is unable to carry out, or is prevented from carrying out, the behaviour in question." Trusting the sociologist's intuitions, it can be concluded that in the case of Kapuścinski, the act of writing was the way of coping with anxiety, and even a mere thought of being unable to continue the act induced uncertainty. A majority of the statements in which we hear the direct voice of the author of The Emperor are similar: one can sense hesitation, indecisiveness, a permanent lack of stability. It seems to be a consequence of the choice Kapuścinski made when he chose to surrender himself to literature and let his existence revolve around it. The price for doing so was loneliness and difficulty in finding his way in life outside of literature. The necessity of writing is the reason why Kapuściński finds himself constantly teetering between the reality and literature, between what becomes synonymous with the lack of control, plunging into chaos, 
and a sense of security and ability to maintain order. As Paweł Rodak (2011, p. 53) rightly observes, "The everyday existence of the writer is constituted through writing, and if for any reason writing becomes absent, the foundations of his existence are eroded." The erosion can be easily seen in the fear of the fruitlessly spent, merely passed and not experienced days, which in the future could lead to an idea for yet another book. The non-writing wasted days made Kapuściński extremely harsh on himself. In one of the entries, he acknowledges that "the price for talent is always some kind of abnormality" (Kapuściński, 2007a, p. 207).

Ryszard Kapuścinski is a paradox-ridden character. On one hand, he admits that "people are his woods" (ibid., p. 122), he needs their presence and talks in order to create; on the other hand, people are the cause of 'halts' in the creative process. In a note about The Guardian London editorial offices, mentioning tons of papers on desks, noise, hundreds of ringing phones, he admits, "I like this world, preoccupied, tense, chatty, slightly dingy and mad, I immediately feel there on my territory at home" (ibid., p. 106). Nevertheless, on the following pages he pictures himself as a man who hates phone calls, wanting to liberate himself from the omnipresent ringing, striving to keep his surroundings in order, from the desk in his study to the streets crossed during numerous travels: "Walking somewhere along the grimy streets and seeing the squalid houses, broken windows, dirty backyards, I immediately want to put everything in order, repair, paint. I feel a sick environment as a disease of my own, there is a physical relationship between myself and my surroundings" (ibid., p. 170). This symbiosis required from Kapuściński to become involved in what was happening around him, to continually make decisions with no guarantee that any activity would make the world closer to what he wished it to be. The writer's inherent contradictions also had a direct bearing on his creative output. Some entries give accounts of the endless journeys (note: not of returns); at times, the reporter wakes up in the middle of the night with an overwhelming urge (bordering on insanity) to set off, treating it as an alternative to writing. Elsewhere, he admits that the constant change of places has an impoverishing effect, that the space he occupies becomes smaller:

Our departures are always marked by a kind of finality, a deep sadness of a loss.

My homeland is widespread

it consists of addresses in different countries, on different continents,

it is made up of hundreds of doors I know how to open, buses whose numbers I remember, 
streets, stops, newspaper stands

faces

voices. (Kapuściński, 2007a, p. 158)

Toby asks how I feel when I leave. Terrible! I always lose something when I leave, every departure entails irreversibility. (ibid., p. 179)

The passages from Lapidarium, exemplifying the first-person statements, reveal to us Ryszard Kapuściński-a writer, a character about whom the author may talk openly and, even more importantly, is able to do it. There is no doubt that for Kapuściński-a writer art is valued above all else, pushing real life aside, to the shadow. Writing provided him with a sense of security, as the world constructed in literature-contrarily to that starting right 'under the skin'-could be kept under control. In the end, the fear of abandoning or even temporarily giving up literature seems impossible to overcome. This is most likely why Kapuściński openly admits he does not like the sun, preferring autumn and darkness ("Become fond of darkness. [...] darkness can also protect your peace. [In autumn-W.B.] the pace of life slows down, people prefer staying indoors, giving you more time to focus on your work" (Kapuściński, 2008a, p. 258).); he sets out time and again, choosing to suffer mentally and physically only to be able to write. This behaviour exhibits symptoms of sanctification of the artist's work, which was discussed by Daniel Fabre in an interview with Paweł Rodak (2009, pp. 235-236). The act of writing demanding sacrifice and risking one's own life leads to physical self-destruction, which in turn fits into the sanctification model. Another consequence is focusing to a greater extent on one's interior, which is expected to provide inspiration causing tension that compels the creative activity.

\section{$\cos$}

In the volumes of Lapidarium we can find many more indirect statements Kapuściński makes about himself. These include predominantly impersonal utterances, statements formulated in the plural, and quotations from other writers. For the purposes of this article, the author of these utterances is referred to by his initials, RK.

What is interesting about his voice is a poetics of orders, or commandments that RK addresses to Ryszard Kapuściński; a poetics revealing certain duality in the image of the author of Lapidarium. Małgorzata Czerminska (2000, p. 291) points out that "the presence of an appeal, apostrophe, or persuasion addressed to one's self reveals the existence of two 'images of the author' in the text." Whereas the listening ' $I$ ', i.e. Ryszard Kapuścinski, constitutes the diarist's current perception of himself, the 
speaking ' $\mathrm{I}$ ', i.e. RK, is the ideal projection of himself. The function of these statements consisted in leaving a trace behind by means of provoking certain patterns of behaviour and actions in real life. It was a particular way of influencing the reality, performing a causative, disciplining function; in addition, these practices helped in 'self-organization':

Not to fall into the trap of one's own past. (Kapuściński, 2007a, p. 96)

I wish you will always have the ability to wonder. The day you stop wondering-you stop thinking, and above all-feeling. (ibid., p. 96)

It is essential that you retain the ability to experience, that there are things capable of making you marvel at them, causing a shock. It is essential that you are not struck by the heinous illness-indifference. (ibid., p. 200)

Your body talks to you. Listen to what it says. Pay attention. (Kapuściński, 2008a, p. 104)

Avoid the rabble, or you'll end up badly, or it'll drag you down, destroy you. Treat these people like plague carriers, steer clear away from them from afar. The rabble is driven by a will to conquer, an envious passion for annihilating everything. The rabble's desire is to wreck your peace, prevent you from working and the humanity-from making progress. The rabble always moves backwards, towards the rear, it's moving-to be moveless. It wants only one thing-to bog you down. You won't be able to resist it because you're too weak. There's only one solutionat all costs steer clear from making the first step towards the bog. The first step is decisive. But how many situations there are when it's difficult to realize that it has been that first, and at the same time final step. (Kapuściński, 2007a, p. 55)

Thursday, 30.11.1995

Write down, write down more! (ibid., p. 365)

RK's statements pose an attempt at pinpointing the sense of his own self-RK-a man. Becoming aware of the dichotomy between the speakers in Lapidarium is the key to further interpretations. Who, then, is RK-a man? The emerging picture seems to be far more depressing than that created by Ryszard Kapuściński-a writer. First of all, the man is perceived as a problem for himself as well as an individual 'poisoning' the surrounding people with his misery. It is a person deprived of home, possessing only a suitcase, frequenting many places, but without a fixed place of residence. Over time, he begins to regard himself as a separate entity, a past accumulated in itself, a lonely island about which hardly anything can be said 
with certainty. The only thing known is that those who can hurt him the most are his closest ones. Relations with the surroundings are also more difficult to maintain. Those who come, who are born, are no longer for us, they prove useless, someone else's life seems too distant to do anything together. RK-a man chooses Proteus as his role model-a shape-shifting deity, accompanying Kapuściński whenever he wants to avoid intrusive questions (Kapuściński, 2008a, p. 203).

Utterances made by RK-a man also contain contradictions. At one time staying longer in a place is considered a misfortune, at another it becomes his sole desire: "To live in a country long enough to be able to say: I completely don't know it" (Kapuściński, 2007a, p. 453). RK admits he likes autumn, yet he also knows it is the time of depression, slowdown, torpor:

18.11 .96

Around November the weather establishes itself, slipping into long autumn stillness. It's grey and humid. A heavy leaden sky hangs low motionless. From time to time, sudden slimy drizzles pass through, like flocks of wet birds. It's cold, though not yet freezing. It's the time of depression, slowed down blood, traffic accidents, illnesses, and of commotion on the cemetery. (ibid., p. 440)

25 November 2003

Start liking darkness. It's the end of November, days are short, the sun rises late and sets early. For this reason, people feel bad, it's a time of the year that makes one prone to becoming stressed, irritated, upset, depressed.

But it is, after all, possible to tame this dark beast, and maybe even grow fond of it. Because darkness can also protect your peace. The pace of life slows down, people prefer staying indoors, giving you more time to focus on your work. (Kapuściński, 2008a, p. 258)

What constitutes an indisputable link between Ryszard Kapuścińskia writer and RK-a man are the dreams, which revolve around a stay in the desert, a quiet bay, or a monastic cell-in other words, in places devoid of people, where one does not need to listen to what others have to say (it's particularly interesting if we bear in mind the philosophy of dialogue promoted by the author). Persistently going back in his mind to "place-no-place," as Zygmunt Bauman (1998, p. 72) called the desert, the protagonist of Lapidarium reveals his desire to preserve continuity and a sense of stability, to escape distractions. What he found attractive about the open space was a kind of existence 'beyond time,' no need for making decisions, for assuming any responsibility, for passing judgements. It therefore comes as no surprise that the fulfilment of dreams about freedom is achieved through literature. Kapuściński (2007a, p. 206) perceives 
books as "a space that in the course of writing we try to fill in with various scenes, images, textures of words, thoughts, moods." In the world of art, the decision what shall be brought into existence is made exclusively by the author. Moreover, it is a space remaining entirely under his controlno random events can happen, nothing can surprise or hurt him.

Bearing in mind that the selection and layout of the entries in Lapidarium was supervised by the author himself, we could wonder: does the reader encounter the genuine Kapuściński there, or merely an image reflecting how he wanted to be perceived? A partial answer can be found in the notes from the reporter's private archive. Published posthumously, they are centred around two major themes, which are: the act of writing, and the trace of the writing ' $I$ ' (which makes them similar to the volumes of Lapidarium published earlier).

\section{WRITING $^{2}$}

\section{April 1998}

My aim and comfort in writing. It's a granite foundation of Your continuing to be. It's an area where you can be calm, certain-feel that you are needed.

\section{May 1999}

My mode of living makes it difficult to keep regular entries in "Lapidarium" and to write in general.

$* * *$

Time wasted as a writer:

St Anthony's Oxford, Temple University Philadelphia,

DAAD Berlin.

In total: 2 years.

\section{Thursday, 22 July 1999}

I'm not writing at all.

I feel emptiness in my head. Actually-it's different. My head is filled with tenth-rate issues, unimportant trivialities. Any such trifle, not worthy of the least bit of attention-can immediately bother me, occupy my mind, devour my time and emotions, as if it were the best literary idea.

$* * *$

Writing-as the only criterion of the time spent productively.

2 The following excerpts (smaller type) have been taken from Kapuściński (2007b, pp. 10-11). 


\section{' $\mathrm{I}$}

...that he's worn out, weak, exhausted, that anything can easily possess him, boss around, push away the things that are important, truly worthy of reflection.

I have to defend myself against it.

$* * *$

I get up too late: before eight. That's how I lose the most valuable time I have: before noon.

Not good: looking forward to the upcoming meetings: talks, dinners, receptions. It should be the other way round.

Rejoicing at the prospect of meeting the thieves stealing my time?

V. bad!

May 2000

I'm 68 years old

1. I have the right to have less strength

2. I can write something new, but don't have to

3. The world appreciates me more than I do myself, not only for what I write, but for who I am.

and I don't have to sit exams every three months

$* * *$

Keep checking: is his thought carried, filled with non-creative subjects (issues), does it function inspired from within, stimulated by its own sources and energies.

Do not become distracted by non-creative things. ${ }^{3}$

\section{Sunday, 20 February 2005}

Terrible insomnia since 9 p.m. Angry with myself: these poor people in wheelchairs suffer a hundred times more!

(My image of the world should be more concerned about the ailments of the world, affliction, pain, everyday tortures.)

\section{Monday, 17 December 2001}

Good mood.

Firstly-limit external influences.

But secondly-above all DO NOT BECOME HYSTERICAL because of them. Here, the main source of my unhappiness are my delicate nerves, unbridled hypersensitivity.

3 The passage is particularly interesting not only because of the clearly stated aim of the entry, its self-disciplining function, but predominantly due to the author's addressing himself as a distinct person-could that be the germ of egotism? Moreover, it is a mark of Ryszard Kapuściński's belief that the source of talent, of true art lies in the individual-only the individual can be the cause of genuine beauty. In Lapidarium the belief is usually expressed through impersonal statements and quotations. 
$* * *$

Commandments for myself:

- Write a piece about direct investigation. Then, use it as a point of departure for reflections.

- [...] Write a book that could be brought out by a liberal democratic Russian publisher.

- Continuously relativize, show:

complexity;

multiplicity (in addition: dichotomous multiplicity).

$* * *$

Learn how to:

1. save a file;

2. create a new folder;

3. navigate through files and folders;

4. use the programs: Explorer and Windows.

$* * *$

Have a more work-substantial approach to days, to life.

Choose only the necessary, absolutely indispensable, useful for creative work, exclusively for it.

Now I don't have any more time for parties, anniversaries, wedding receptions, any other group festivities. [...]

$* * *$

Be sure to try to do ANYTHING AT ALL!

Read a few pages.

Reply to 1-2 letters.

Make an entry for the next volume of "Lapidarium."

$* * *$

Break the restrictive rule of selection:

would I award the prize to X (who didn't get it), or rather to $Y$ (who got it)?

I'd give it to neither of them!

22 February 2005

$10^{\text {th }}$ gym (first time after so many months.)

$12^{\text {th }}$ walk through the central borough.

Then reading:

for The Other,

for the translators.

Phone calls (4).

The will to read, to accept the outside world, to see, etc., is coming back.

Wednesday, 22 January 2003

My organization of the day seems poor. It's already 11, and I-despite 
having woken up at six in the morning-haven't made a single step on the path to Herodotus. All the time I've been reading something else (Dąbrowska here, Kleiner there, and Didion on top-there are so many interesting things to learn!), making no progress on the path to Herodotus.

That's bad. I definitely need more self-discipline! Get up and immediately set off to Greece! Do not admit any other issues or subjects. Stay focused!

I refused an interview for "Przegląd." Consent-once the book's finished!

Writing letters with Dorota-7.

$* * *$

A lesson learnt from reading Andrzejewski:

Don't become obsessed with old age once you're old. No whining, no grumbling, no rending of garments. One has to live in harmony with the dynamics of the world. And today this stands for: swank, super.

Kapuściński's notes indicate that he made an attempt at introducing order into his life, making it coherent by recording everyday activities, thus exerting a real influence on life. In addition, we can track here firstperson statements that take the form of performatives, of orders directed at himself that have a disciplining function. As a consequence, real life becomes subordinated to literature, which is promoted to the position of a superior value. Anything that is not literature the author regards as a loss, a waste of precious hours. It is worth noting that the creative act has also been emphasized visually.

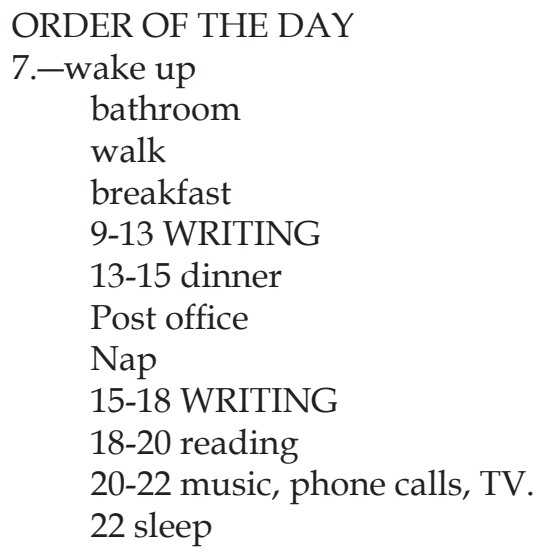

Year 2001. A sketchy balance sheet

TRAVELS 7

Mexico City, March 3-16

Göttingen, March 
USA (30.04-6.05)

Paris, May-June

London, June

Gdynia, 18-21 October

Wrocław, November [...]

14 April 2002

I'm stuck. I've come to a halt. Meanwhile I have to:

- write letters

- "Lapidarium V"

- interviews (a selection)

- book about Latin America

- book about Pinsk

- India, Egypt, Sudan, Nepal.

What distinguishes the entries in Lapidarium from those published in Duży Format (Big Format) is the fact that the latter include more instances of Ryszard Kapuściński talking in the first person about his weaknesses, problems (often with his own self), his struggles as a writer.

$\cos$

To trail traces of a diary in Lapidarium, I shall begin by drawing attention to a special moment-situation, which served as an impulse inducing the author to start writing intimately about himself (Lejeune, 2009, pp. 187-200).

The first volume opens with a 1972 memory of Mexico, when women and men, heading in the opposite directions, formed two circles. At that time, a significant event occurred in the life of Ryszard Kapuścinski: for the first time, he was sent to a posting with his wife and adolescent daughter. The image recollected in the first volume of Lapidarium could be therefore understood as a metaphor of complex family relations, especially if one bears in mind that on several occasions Kapuścinski mentioned how difficult it was for representatives of various generations to reach agreement. To succeed, an individual has to pretend to be someone he or she actually is not (note the literary way of depicting the issue).

In his entries, the author of The Emperor drew a clear dividing line between work, writing and preparations preceding the act (including gathering the materials), and life that goes on beyond literature. Not much time or space is dedicated to the last element, also in Lapidarium. However, one cannot claim that intimate details are altogether absent from the cycle. Many scholars believe that the only hint of the author's private life in the discussed volumes are the descriptions of visiting a doctor and diagnosing the illness. It is not true. Upon close reading of the entries, one 
discovers in them a layer of privacy. It would seem that acting as if against himself, Kapuściński tries to externalize these issues as well. In all the 6 volumes there are 3 instances when the wife, daughter, and presumably the grandson are mentioned:

A dream:

I see a flying helicopter transporting a church tower (the helicopter has no horizontal propellers). The stone tower, tall, adorned with friezeshas been placed on the helicopter roof (the tower and the helicopter are one). There is a bright, clear, summer sky. I'm standing with Kuba on the edge of a city. The helicopter is flying at great speed and begins landing without slowing down. It makes a bend-and at this point tilts, rapidly loses its balance, and turns upside down. The tower is torn off and breaks into pieces in the air. The aircraft is also shattered to bits over the ground, the remains of the tower and the machine fall on the city.

(The day before J. told me the details of the IŁ-62 plane crash near Warsaw.) (Kapuściński, 2007a, p. 132)

Palo Alto, California:

Cinema with Zojka and Mariusz. An old building, gilded gypsum cornices, cheap version of the Spanish-Mexican art nouveau (no shortage of that in California). The cinema-is also: a café, a bar, a restaurant. On the patio, someone's giving a guitar gig. The film is called HARD ROCK LIVE SHOW. (ibid., p. 65)

15.8.96

A.B. told me a story about Paul, or that the TV screen is the whole world: our neighbours in Warsaw have been visited during vacations by a distant cousin-17-year-old Paul. Since we live next door, regularly drop by, and also share the garden and the veranda, we keep in close touch, on a daily basis. Paul's intrigued me from the start. He's nice, polite, but showing the indifferent politeness of someone belonging to a different world. We've already talked a few times. It's his first time in Europe. He doesn't know exactly where that is. More importantly-he's not interested in knowing. He doesn't want to visit any cities, go sightseeing [...]. As soon as he arrives in a new city, he sits down in a hotel room and switches on the TV. CNN is his channel of choice. (Kapuściński, 2007, pp. 359-360) $)^{4}$

4 Writing about Ryszard Kapuściński's grandson, Artur Domosławski (2010, pp. 288-289) recalls a similar story: "Once, when Brendan visited Poland, Rysiek tried to become close, to tell something about himself, the family, Poland. But he couldn't get through. The boy acted as if he had never left Canada: he switched the TV to English-speaking channels, and this was the sole thing that interested him." 
Each of the above statements was enveloped in a general synthesis, a theory on the society, young generation, or modern world. The brief remarks constituting traces of the private life were shrouded by issues that have no relevance whatsoever to it. The author uses them merely as pretexts to present a pinpoint image of himself, to indicate his existence; it is an attempt to forcibly express that Ryszard Kapuściński's 'I' does not want to or cannot limit himself to being only a writer. It should be emphasized that another common quality shared by all these passages is also the fact that the author of The Shadow of the Sun does not reveal himself in them by speaking in the first person. Even the situation involving "Kuba," the writer's wife, is recalled as a part of a dream. One should not consider this behaviour to be devoid of importance, or ignore it, especially bearing in mind the motto of the first volume of Lapidarium, which serves also as the title of this text: "Writing is as much as picking out and passing over. Just like in a poem, when writing a diary one can afford a long spell of silence, an interruption in the middle of a word." After all, a diary creates space not only for the well-established, but also for what has been partially omitted, passed over in silence, subjected to selection, in order to extract the sense of the life lived. As the classic reminds us, when it comes to the selection, "the diary takes it to the extreme by laying down the results and building these results into a series" (Lejeune, 2009, p. 179). Recalling the function performed in Kapuściński's entries by individual sentences and orders, pointing out their performative nature, it would be difficult to disagree with this claim. The French scholar also considered the diary to be the art of "repetitions and variations" (ibid., p. 178). Striving to describe the main theme of Lapidarium, we refer to literature, to the act of writing, and to Ryszard Kapuściński. The author becomes a subject of self-interest as seen from two perspectives: as an artist and as a man. This kind of creativity, the casual writing style characteristic of Lapidarium, allows him to focus on himself. In an interview with Jarosław Mikołajewski, Kapuściński (2008b, p. 136) recalls the beginnings of his adventure with Lapidarium: "I started writing Lapidarium, a cycle of short reflections, and at that time I also returned to poetry. It was a colossal leap, not only in the literary, but also the spiritual sense, because the subject of a reporter are other people and the world, and the subject of reflection and poems may be one's own experiences." An attempt at preserving in fragments what he knew about himself, often concealing these truths, employing other people's voices, as well as communicating the same information in a number of ways, is a recurring motif in Lapidarium. "Everything revolves around this: the desire of repetition and the fear of repetition. The rhythm of repetitions. They enslave the man," says RK in the third volume of Lapidarium (Kapuściński, 2007a, p. 423; bold added by W.B.). 
What is also worth mentioning is the fact that continuity, a feature typical of the diary, is also preserved in the discussed work, although dates are not written down in a systematic manner (which shall be discussed below). The subsequent volumes of Lapidarium are numbered, with each encompassing one historical period during which it was written (except the second volume, which includes entries from 1989); all of them share the same graphic design and are linked by themes, the speaker's way of expressing himself over a number of years, and, essentially, by a sense of unity in being distinct. As claims Lejeune (2009, p. 176), "The notebook [...] operates at the level of the fantasy that Paul Ricoeur calls "narrative identity': it promises some minimal measure of unity."

At this point it is worth reflecting on what Lejeune considers to be the defining quality of the diary: the capturing of time along with the dating system. "Keeping a diary is surfing on time. Time is not an objective, continuous thing that the diarist tries to portray from the outside using tiny discontinuous brushstrokes, as a novelist would. He is himself caught up by the moment, he is sculpting, moving along with it, emphasizing certain lines and directions, transforming this inescapable drift into a dance" (ibid., p. 182), says the author of On Diary. Writing in a similar vein, Kapuściński (2007a, p. 262) quotes from Seneca, "Live in time-independent from time." One could venture a guess that the chaotic dating system stems from the writer's understanding of this category. Writing a diary is "a struggle against time" (Lejeune, 2009, p. 170). The author of Lapidarium either does not believe in that statement, or does not know how to put it into practice. Dates, that is links with reality, are not placed in a chronological order and appear occasionally-which is related to the attitude the author of The Emperor (a person who cannot escape the fetters of literature, as it provides him a shelter) exhibits toward 'real' life. In The Shadow of the Sun, Kapuściński discusses the concept of time as understood by the Europeans and the Africans. For the former, it exists in an objective manner, is independent from the individual, and requires obedience and subordination. The people of the Dark Continent do not share this view. For them, time is "matter that may spring to life, but falls into a state of hibernation, even non-existence, if we do not direct our energy toward it. It is a subservient, passive essence, and, most importantly, one dependent on man" (Kapuściński, 2001, p. 17). Following this approach, it becomes easier to discover hints of a diary in Lapidarium, in spite of the peculiar dating system. The motto opening the fourth volume of the cycle is a deliberate quote from William S. Burroughs: "Life stories are not an ordered narrative from birth till death. Rather, they are fragments collected at random" (Kapuściński, 2008a, p. 9). The absence of chronology reflects 
the writer's obsession with the passing time. Thus, it is justified to regard the discussed collection as a 'diary' of sorts, written by a man living in liquid times. The notes are indicative of the way in which reality is perceived and described. For the author, it is "a constant sum, made up of an unchanging number of components, particles, elements. A change-involves moving the fragments to different places, arranging them in various configurations" (Kapuściński, 2007a, p. 313). This also explains how Lapidarium was born: "First, they write themselves in A4 notebooks, and then I rewrite and rewrite them. Then, I cut them up into fragments, and then glue the fragments together. Next, I read them again and make choices. It is a large-scale selection, because what gets into the book is roughly a quarter of what I've written. The selection process is very continuous" (Kapuściński, 2002a).

In his definition of the diary, Lejeune (2009, p. 179) described it as "a series of dated traces." Later, clearly giving a wink to the reader, he agreed to a minor yet crucial change, saying that "the diary is a narrative of traced dates" (ibid.). Considered from this perspective, the Lapidarium series becomes ever closer to a diary.

\section{References}

Bauman, Z. (1998). Parvenu and Pariah: The Heroes and Victims of Modernity. In. Z. Bauman, Postmodernity and its Discontents (pp. 83-94). Cambridge, UK: Polity Press in association with Blackwell Publishers Ltd.

Czermińska, M. (2000). Autobiograficzny trójkąt: Świadectwo, wyznanie i wyzwanie. Kraków: Towarzystwo Autorów i Wydawców Prac Naukowych Universitas.

Domosławski, A. (2010). Kapuściński non-fiction. Warszawa: Świat Książki.

Giddens, A. (1991). Modernity and Self-Identity: Self and Society in the Late Modern Age. Stanford, CA: Stanford University Press.

Grochowski, G. (2000). Od empirii do narracji: Imperium Ryszarda Kapuścińskiego. In G. Grochowski, Tekstowe hybrydy: Literackość i jej pogranicza. Wrocław: Fundacja na Rzecz Nauki Polskiej.

Horodecka, M. (2010). Zbieranie głosów: Sztuka opowiadania Ryszarda Kapuścińskiego. Gdańsk: Słowo/Obraz Terytoria.

Kapuściński, R. (2008a). Lapidaria IV-VI. Warszawa: Biblioteka Gazety Wyborczej. 
Kapuściński, R. (2008b). "Pisanie wierszy jest dla mnie luksusem." Z Ryszardem Kapuścińskim rozmawia Jarosław Mikołajewski. In R. Kapuściński, Wiersze zebrane (pp. 135-137). Warszawa 2008: Biblioteka Gazety Wyborczej.

Kapuściński, R. (2007a). Lapidaria. Warszawa: Czytelnik.

Kapuściński, R. (2007b). Wstać i wyruszyć do Grecji. Duży Format, 4 (715), 10-11.

Kapuściński, R. (2002a). Ryszard Kapuściński's speech at the launch of Lapidarium V,November 7, 2002, www.kapuscinski.info/przemowienie-ryszarda-kapuscinskiegopodczas-premiery-lapidarium-v.html [last accessed: May 28, 2012].

Kapuściński, R. (2001). The Shadow of the Sun. (K. Glowczewska, Trans.). New York: Vintage Books.

Lejeune, P. (2009). On Diary. (J.D. Popkin \& J. Rak, Eds.; K. Durnin, Trans.). Manoa: University of Hawaii Press.

Nowacka, B., \& Ziątek, Z. (2008). Ryszard Kapuściński: Biografia pisarza. Kraków: Społeczny Instytut Wydawniczy Znak.

Rodak, P. (2011). Między zapisem a literaturą: Dziennik polskiego pisarza w XX wieku (Żeromski, Nałkowska, Dąbrowska, Gombrowicz, Herling-Grudziński). Warszawa: Wydawnictwo Uniwersytetu Warszawskiego.

Rodak, P. (2009). Pismo, ksiazka, lektura: Rozmowy: Le Goff, Charter, Hebrard, Fabre, Lejeune. (K. Pomian, Pref.). Warszawa: Wydawnictwo Uniwersytetu Warszawskiego. 